\title{
Clinical Trials Cooperative Groups Human Tissue Resources
}

National Cancer Institute

\section{Source}

National Cancer Institute. Clinical Trials Cooperative Groups Human Tissue Resources. NCI Thesaurus. Code C16196.

A collection of banked tumor specimens from large numbers of uniformly treated cancer patients with a variety of malignancies. 